\title{
Eating insects - from acceptable to desirable consumer products
}

\author{
A.R.H. Fischer iD \\ Wageningen University, Social-Sciences, Marketing and Consumer Behaviour, Hollandseweg 1, 6706 KN Wageningen, \\ the Netherlands; arnout.fischer@wur.nl
}

(C) 2021 Wageningen Academic Publishers

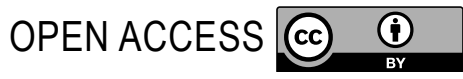

EDITORIAL

\begin{abstract}
There is a considerable amount of research into consumer acceptance of insects as food in high-income countries. Most of this research has focussed on identifying the reasons why consumers either resist or are enticed into trying eating insects. In this paper I argue that consumers trying insects is an insufficient, albeit necessary first, step towards creating a relevant market for insects as food. I advocate that the creation of such a market requires an increase in research into what makes insect products desirable rather than merely acceptable.
\end{abstract}

\section{Introduction}

Insect-eating in industrialised high-income countries has received increasing attention in the last 20 years. Initially, responses were those of surprise and even disgust. Much of the research since has focussed on consumer acceptance of insects and which product properties (e.g. whole insects or insect flour, Gmuer et al., 2016) or personality traits (e.g. neophobia, Verbeke, 2015) evoke more resistance. This approach appears to be the prevailing approach to date (see the review of recent publications by Dagevos, 2020).

\section{From occasional snack to regular consumption}

The study into determinants of resistance to insect-eating has delivered many relevant insights; for example, that not all insect species are liked equally well (Fischer and Steenbekkers, 2018). The idea of eating insects no longer seems as novel, weird and scary as it was a decade ago (see e.g. Schlup and Brunner, 2018). High-income societies may have become used to the idea of eating alternative proteins, including insects. This may be due to continued attention towards insects as food, for example through insect festivals and other initiatives. Yet, lack of resistance is an insufficient, albeit necessary, precondition for consumer acceptance in the broader sense of the word acceptance (Fischer and Reinders, 2021). Broader acceptance of insects as food implies that insect foods will capture a stable, relevant or even substantial, share of the food market. The frequently encountered willingness to try insects once is promising, but this kind of acceptance does not necessarily result in a steady willingness to include insects in the regular diet (Tan et al., 2016). Some examples of insect marketing can be interpreted as capitalising on the novelty and willingness-totry-once factor. This relates to the curiosity that consumers may have about insect-eating. The limited sales of Mexican grasshoppers as snacks, which began in 2017 in the stadium of the Seattle Mariners (major league baseball, Washington, USA), are still going strong, possibly because it became part of the experience of the Seattle game. The ongoing sales could be due to the limited availability, the huge number of spectators in the stadium, grasshoppers being sold in a single stadium, and the curiosity of a one-off rather than a regular snack. Similarly, high protein energy bars with insects have seen some success. However, they do not seem to be gaining a large market share, which may be due to the fact that their main advantage over other protein bars is their novelty and their ability to satisfy customer curiosity. While these initiatives may be important 'pathfinders', they are an insufficient indicator that broad acceptance is on the horizon. In my view they will not create such acceptance in mainstream food sales.

\section{Making insect products desirable}

Removing resistance and raising the curiosity to try once, are necessary but insufficient conditions for creating broader acceptance and the associated market share. Therefore, I argue that we need to focus at least part of the consumer research on making insect products desirable. This implies a shift in focus from understanding how we can prevent insect products from being rejected. If we 
can create unique, desirable product properties that are linked to the use of insects, these products may be really accepted for long-term consumption by a substantial group of consumers. Not because of the insects per se, but because of the consumer-relevant product benefits provided by the insects.

An expected precondition for the success of such products is that the innovation needs to fit easily with existing behaviours. At the same time, these products should have some relative advantage over current options. It has been argued that a lack of success in fitting insect products into the existing experience of consumers contributed to past rejection (Schösler et al., 2015). This lack of success may be caused by insufficient efforts to create and position insect products that are compatible with existing consumer knowledge, simple to prepare and fit into daily life, and have a clear competitive advantage over the alternatives (Shelomi, 2015). The failed introduction of the insect-burger in the Netherlands, in the mid-2010s, is a case in point. The burger was mainly marketed as more sustainable than meat. But supermarkets positioned it on the vegetarian meat-alternative shelf. It was therefore in direct competition with plant-based meat alternatives, while no claims about the competitive advantage of insect products were made. Even worse, the price was higher than many plant-based alternatives, and according to many, the taste was inferior too. This contributed amongst other things to the failed introduction of the product (House, 2016).

\section{The sustainability argument}

Even when avoiding direct competition with plant-based meat alternatives, it is very hard to use sustainability as the main benefit to gain market share. There is substantial evidence that, on its own, sustainability is an argument that convinces only a very small group of consumers $(<5 \%$, see e.g. Van Dam and Van Trijp, 2011). It is simply not sufficient to determine a dietary change for most consumers, especially because sustainable products, including those based on insects, are generally more expensive than conventional ones. This means that consumers have to make a trade-off between price (and possibly other properties as well) and sustainability. In many cases sustainability is a relatively weak argument when making shopping decisions because the individual consumer does not immediately benefit. The reason why consumers still claim that sustainability is very important to them can be understood if we consider the difference between the focus on immediate benefits for the self, in the here-and-now, and the relevance of voiced opinions that tend to consider global long-term effects to a greater extent (Van Dam and Fischer, 2015).

\section{Insect-eating as an experience}

The success of sustainability marketing increased after it was linked to relevant, immediate, personal benefits. For example, sales of sustainable chocolate and coffees started to soar when specific flavours and exotic experiences associated with a consumption moment were related to storylines from a single region (or even plantation). When enjoying, for example, a prime Colombia highland coffee from a specific region, the idea of environmental and worker protection becomes part of the experience of drinking the coffee. Sustainability is no longer an isolated argument but part of the larger positive consumer experience. An example of insect-eating where such a comprehensive experience is created, is the use of red fire ants for their specific acidic taste and the local harvesting of the insects by the restaurant Noma (at the time the most highly rated restaurant in the world). The insect is part of the overall experience of dining at the best restaurant in the world, rather than just being judged as an insect food.

Besides creating new product experiences, as Noma did, another way of creating an experience is to promote the notion of traditional insect consumption. Efforts in Japan to revitalise a dwindling tradition of insect-eating promote these insects as recognised, accepted, and cherished foods. The experience relates to the traditional values and culture of the relevant region (Nonaka and Yanagihara, 2020). Again, the experience goes beyond the insect itself and involves being part of ancient culinary traditions. It will not be easy to transfer such traditions, or the experience of eating at Noma, to a larger group of consumers in highly industrialised rich countries. But there may be an inroad through the careful introduction of desirable, exciting traditional, ethnic dishes - that just happen to contain insects.

\section{Eating insects for their properties}

While the Japanese and Noma examples focus on the marketing of an insect-eating experience in a specific social context, another approach could be to carefully select and use insects for their product properties. For example, the giant water beetle in Thailand is used in curry pastes because of its specific flavour (Tan et al., 2015). The popular demand for red M\&Ms, which were discontinued in the US during the 1970s after negative reports about the safety of artificial red colourants, led the Mars company to look for a natural bright red food colouring. They ended up using carmine. Carmine is a bright red, insect(cochineal)-based food dye. Many other food companies also use this natural red colouring. The fact that carmine is an insect product is not a central argument for its use and is hardly ever mentioned. The consumer benefit is obvious - a red colour which is natural. Different species of insects may have specific flavouring, olfactory, texturing 
and/or visual properties that could lead to products with uniquely desirable properties from the point of the view of consumers. These benefits are experienced immediately at the moment of consumption. It is this immediate satisfaction that contributes to their desirability. Creating such immediately satisfying consumer properties in insect products could be a key factor for their success. Current insect product development often relies on insects that we know how to breed and process regardless of consumerrelevant properties. A shift to a consumer-centred insect market will require an effort in product development to find, learn to breed and use insects, based on the unique benefits relevant to the consumer.

\section{Conclusion}

I have showcased two approaches to increase insect consumption in high-income countries: (1) marketing insects as a social and cultural experience; and (2) identifying and using insects for their clear product property benefits from a consumer point of view. These cases suggest that a successful direction for the future may lie in creating integrated joyful experiences in which insect products are central and capitalising on insects to create products desirable for their properties and not their origin.

Both approaches align with my opening argument that consumer-directed entomophagy product development should be the next step. We need to move on from merely removing consumer objections to insects as a protein source, and the associated supply-driven approach. While the research on how to remove the repulsion and rejection associated with eating insects has given and will continue to give us many insights into overcoming barriers, for complete acceptance this is not enough. It is time to look for ways to move forward. I would call for the research on insects as food to focus on consumer products in highincome countries, and to make the shift from production to consumer-demand-driven efforts. Given the groundwork of the last 20 years, and our knowledge about how to deal with the rejection of insect products, I have high hopes that we can come up with exciting new ideas and research that moves insects as consumer food to the next phase - from acceptable to desirable.

\section{References}

Dagevos, H., 2020. A literature review of consumer research on edible insects: recent evidence and new vistas from 2019 studies. Journal of Insects as Food and Feed 7(3): 249-259. https://doi.org/10.3920/ JIFF2020.0052
Fischer, A.R.H. and Reinders, M.J., 2021. Consumer acceptance of novel foods In: Galanakis, C.M. (ed.) Innovation strategies in the food industry. Academic Press, London, UK, pp. 271-292. https:// doi.org/10.1016/B978-0-323-85203-6.00013-X

Fischer, A.R.H. and Steenbekkers, L.P.A., 2018. All insects are equal, but some insects are more equal than others. British Food Journal 120: 852-863. https://doi.org/10.1108/BFJ-05-2017-0267

Gmuer, A., Nuessli Guth, J., Hartmann, C. and Siegrist, M., 2016. Effects of the degree of processing of insect ingredients in snacks on expected emotional experiences and willingness to eat. Food Quality and Preference 54: 117-127. https://doi.org/10.1016/j. foodqual.2016.07.003

House, J., 2016. Consumer acceptance of insect-based foods in the Netherlands: academic and commercial implications. Appetite 107: 47-58. https://doi.org/10.1016/j.appet.2016.07.023

Nonaka, K. and Yanagihara, H., 2020. Reviving the consumption of insects in Japan: a promising case of hebo (Vespula spp., wasps) by high school club activities. Journal of Insects as Food and Feed 6: 45-50. https://doi.org/10.3920/JIFF2019.0005

Schlup, Y. and Brunner, T., 2018. Prospects for insects as food in Switzerland: a tobit regression. Food Quality and Preference 64: 37-46. https://doi.org/10.1016/j.foodqual.2017.10.010

Schösler, H., De Boer, J., Boersema, J.J. and Aiking, H., 2015. Meat and masculinity among young Chinese, Turkish and Dutch adults in the Netherlands. Appetite 89: 152-159. https://doi.org/10.1016/j. appet.2015.02.013

Shelomi, M., 2015. Why we still don't eat insects: assessing entomophagy promotion through a diffusion of innovations framework. Trends in Food Science \& Technology 45: 311-318. https://doi.org/10.1016/j.tifs.2015.06.008

Tan, H.S.G., Fischer, A.R.H., Tinchan, P., Stieger, M., Steenbekkers, L.P.A. and Van Trijp, H.C.M., 2015. Insects as food: exploring cultural exposure and individual experience as determinants of acceptance. Food Quality and Preference 42: 78-89. https://doi. org/10.1016/j.foodqual.2015.01.013

Tan, H.S.G., Fischer, A.R.H., Van Trijp, H.C.M. and Stieger, M., 2016. Tasty but nasty? Exploring the role of sensory-liking and food appropriateness in the willingness to eat unusual novel foods like insects. Food Quality and Preference 48 Part A: 293-302. https:// doi.org/10.1016/j.foodqual.2015.11.001

Van Dam, Y.K. and Fischer, A.R.H., 2015. Buying green without being seen. Environment and Behavior 47: 328-356. https://doi. org/10.1177/0013916513509481

Van Dam, Y.K. and Van Trijp, H.C.M., 2011. Cognitive and motivational structure of sustainability. Journal of Economic Psychology 32: 726-741. https://doi.org/10.1016/j.joep.2011.06.002

Verbeke, W., 2015. Profiling consumers who are ready to adopt insects as a meat substitute in a Western society. Food Quality and Preference 39: 147-155. https://doi.org/10.1016/j.foodqual.2014.07.008 
